\title{
En ung kvinne med akutte magesmerter
}

\author{
En kvinne i 30-årene kom til legevakten med akutte magesmerter \\ og vaginalblødning. Ved magesmerter hos kvinner i fertil alder må gyne- \\ kologiske akuttdiagnoser stå høyt på listen over differensialdiagnoser. \\ En negativ graviditetstest ble i dette tilfellet avgjørende for videre hånd- \\ tering og valg av sykehus.
}

En kvinne i begynnelsen av 30-årene kom til legevakten med magesmerter som hadde vart $i$ omtrent ti timer. Smertene debuterte akutt som takvise smerter i nedre del av abdomen og spredde seg etter hvert til hele høyre side av abdomen, med utstråling til høyre kravebein. Hun fortalte at hun hadde hatt liknende, men mer moderate smerter 14 dager tidligere, som hadde gått gradvis over etter et par dager. I tillegg hadde hun hatt vaginalblødning siste 12 dager. Pasienten hadde selv oppfattet dette som menstruasjonsblødning. Hun hadde født et barn ca. 11 måneder tidligere og hadde etter det hatt kun én menstruasjon, 28 dager før den aktuelle blødningen startet. Hun hadde gjenopptatt samlivet etter fødselen, og de hadde foreløpig brukt kondom som prevensjon.

Blødningens varighet og tidsmessige sammenfall med buksmertene gjorde det naturlig å se disse symptomene i sammenheng og vurdere en gynekologisk diagnose. Det kunne imidlertid ikke utelukkes at det var et tilfeldig sammenfall av symptomer, og andre akutte gastrointestinale tilstander ble også vurdert.

Usikkerhet knyttet til om pasienten skulle innlegges ved kirurgisk eller gynekologisk avdeling skapte praktiske utfordringer. $\mathrm{Pa}-$ sientens symptomer startet i fellesferien, og denne dagen var det ingen gastrokirurger tilgjengelig ved nærmeste sykehus. Ved en gastrokirurgisk diagnose måtte hun derfor ha blitt overflyttet til et annet sykehus, vel en time unna. Dette sykehuset hadde imidlertid ingen gynekolog $\mathrm{i}$ beredskap, noe de hadde ved det førstnevnte sykehuset.

Pasienten hadde tidligere på dagen vært $\mathrm{i}$ kontakt med sin fastlege. Etter dette hadde hun tatt en graviditetstest hjemme, som hun oppga å være negativ. Derfor ble graviditetsrelaterte diagnoser vurdert som mindre sannsynlig, til tross for langvarig blødning. Med gallestein som tentativ diagnose ble pasienten transportert til sykehuset der de hadde gastrokirurg på vakt.

Ved klinisk undersøkelse i akuttmottaket var abdomen bløt, men med reflektorisk spenning. Abdomen var palpasjonsøm i alle kva- dranter, mest uttalt i nedre, høyre kvadrant. Pasienten hadde lette, takvise smerter med forverring ved bevegelse og dyp inspirasjon. Psoastest var positiv. Det var normale tarmlyder og ingen bankeømhet over nyrelosjene. Hemofec-test var negativ. For øvrig var pasienten respiratorisk og sirkulatorisk stabil, med normalt blodtrykk (117/73), puls (83 slag/min) og temperatur $\left(37,6^{\circ} \mathrm{C}\right)$. Foruten vaginalblødning og abdominale smerter ved bruk av bukpressen var naturlige funksjoner upåfallende.

Akutt abdomen er en vanlig problemstilling $i$ akuttmottaket. Akutte smerter i abdomen er oftest ufarlig hos yngre voksne, men kan være vanskelig å skille fra potensielt livstruende sykdom som krever akutt diagnostikk og behandling $(1,2)$ I figur 1 gis en oversikt over ulike differensialdiagnoser ved akutt abdomen. Pasienten ble innlagt med tentativ diagnose gallestein, men vi fant dette lite sannsynlig da smertene var konstante med lokalisasjon til nedre del av abdomen. Smerter ved gallestein er derimot ofte takvise, kolikkaktige og lokalisert under høyre kostalbue. Smerter i nedre høyre kvadrant kunne peke $\mathrm{i}$ retning appendisitt, og positiv psoastest ga mistanke om retroperitoneal affeksjon, men foreløpig var det ingen entydige funn. Som mest sannsynlige diffensialdiagnoser på dette tidspunktet vurderte vi gynekologiske diagnoser som corpus luteum-cyste med blødning, torkverte ovarier, patologisk graviditet, salpingitt samt spontanabort.

Blodprøver ved innkomst viste humant choriongonadotropin (HCG) i serum på 4544 (0-4). Hemoglobin $(\mathrm{Hb})$ var på 8,9 (11,715,3), og sank til 7,8 noen timer senere. mellomtiden var det gitt vanlig intravenøs væskebehandling. Ultralyd abdomen viste «store mengder fri væske i buken med ekkomønster forenelig med blod» (fig 2) og «uregelmessig oppfylning på ca. $5 \mathrm{~cm}$ like kranialt for uterus, forenelig med ekstrauterin graviditet» (fig 3).

Det høye nivået av serum-HCG tydet på at pasienten var - eller nettopp hadde vært -

\author{
Peter Erik Petersen \\ p.e.petersen@studmed.uio.no \\ Det medisinske fakultet \\ Universitetet i Oslo \\ Kjell Isachsen jr. \\ Avdeling for fødselshjelp og kvinnesykdommer \\ Kristiansund sykehus*
}

\section{Mark Berner Hansen}

Kirurgisk avdeling $\mathrm{K}$

Bispebjerg Hospital

København

\section{* Nåværende adresse: \\ Kvinneklinikken}

Sykehuset Telemark

Se kommentar på side 2162 


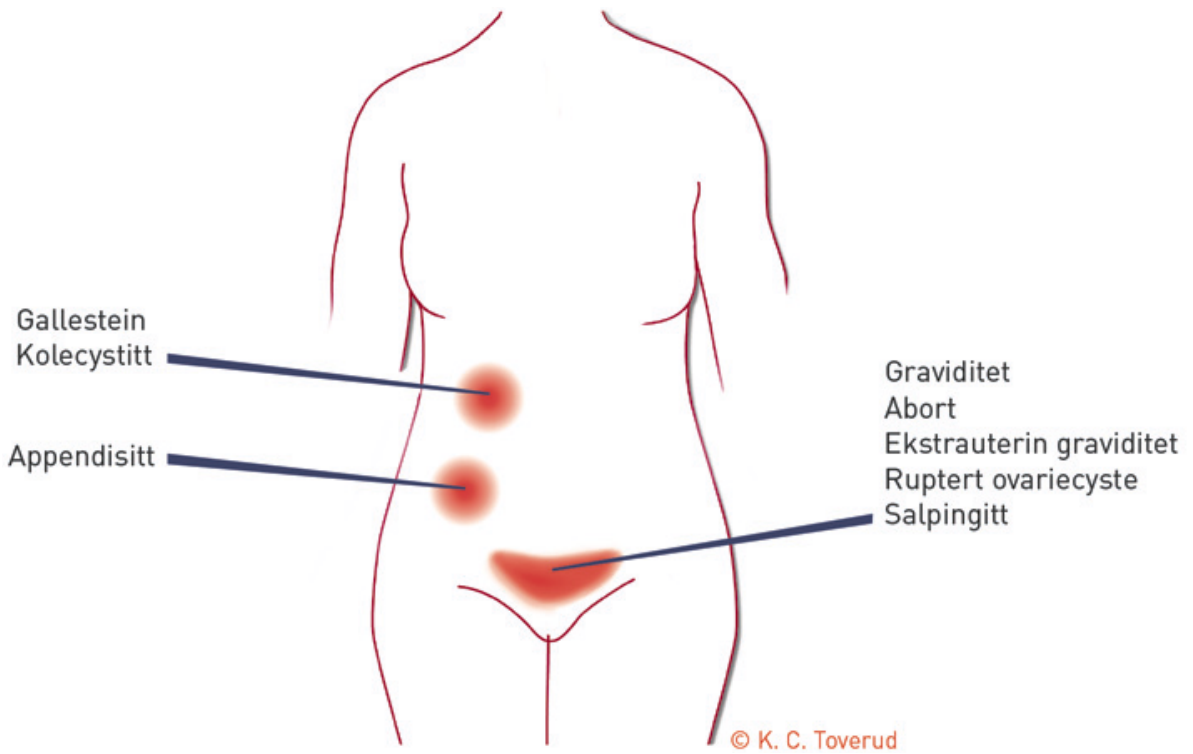

Figur 1 Typisk smertelokalisering for differensialdiagnoser som ble vurdert hos pasienten

gravid, enten intra- eller ekstrauterint. Dette sto i motsetning til testen pasienten hadde tatt hjemme, som var negativ for HCG i urin. Vi mistenkte nå ekstrauterin graviditet, primært tubar graviditet med rumpert tube (3). Dette er en potensielt livstruende tilstand, som krever rask intervensjon. Pasienten var nå på et sykehus uten gynekolog, og igjen ble lokaliseringen av pasienten et tema. Var tilgang til gynekologisk kompetanse så viktig at det kunne veie opp for den økte risikoen det innebar å transportere pasienten til et annet sykehus?

Pasienten var fremdeles sirkulatorisk stabil, men etter å ha konferert med gynekolog ble det besluttet at pasienten ikke skulle flyttes. Et gastrokirurgisk operasjonsteam skulle foreta diagnostisk laparoskopi på indikasjonen abdominal katastrofe med fri væske. Pasient og pårørende ble informert om diagnosen, risikoen forbundet med inngrepet og om konsekvensene av en eventuell salpingektomi.

Tuberuptur er en alvorlig komplikasjon ved ektopisk graviditet, med fare for hypovolemisk sjokk og kardiovaskulær kollaps. I en slik situasjon må hovedfokus være å redde pasientens liv. Å bevare tubene for å bevare fertilitet vil være sekundært til dette.

Ved laparoskopi fant man ca. 2 l blandet friskt og gammelt blod i bukhulen. Det var normale forhold ved uterus, egglederne og ovarier bilateralt, med unntak av fimbriae på venstre side som var lettblødende med et perifert fastsittende koagel.

Størrelsen på den intraabdominale blødningen sammenholdt med de relativt sparsomme forandringene ved venstre fimbriae skapte usikkerhet om det observerte koagelet kunne være identisk med oppfylningen som ble observert på ultralyd. I så fall ville man måtte gå videre med en venstresidig salpingektomi, men ettersom kvinnen var i fertil alder ønsket man ikke å fjerne egglederen uten sikker indikasjon.

Det ble gjort en strukturert gjennomgang av alle øvrige organsystemer $i$ bukhulen, og noe lengre midtkaudalt $i$ abdomen lokaliserte vi en lettblødende oppfylning $i$ omentum majus som var ca. $4,5 \mathrm{~cm}$ i diameter. Oppfylningens størrelse og form sannsynliggjorde at den representerte hovedfokus for blødningen. Vi antok at det dreide seg om en abdominal graviditet med implantasjon i omentum majus. Oppfylningen ble resecert sammen med assosiert omentum majus, mens eggledere og ovarier ble spart. Operasjonen forløp ukomplisert, og pasienten ble utskrevet i velbefinnende to dager senere.

Histologisvaret viste «omentumresektat med ekstrauterin graviditet». Det ble også funnet «mikroskopiske fragmenter av viabelt tubeepitel». Vi konkluderte derfor med at det har foreligget en tubar abort med sekundær implantasjon i omentum majus.

Histologisvaret bekreftet diagnosen abdominal graviditet med (sekundær) implantasjon i omentum majus. Basert på sykehistorien til pasienten kan vi anta at hun har hatt en ekstrauterin graviditet $i$ venstre tube og at smertene hun opplevde to uker før det aktuelle skyldtes en tubar abort. Deretter har

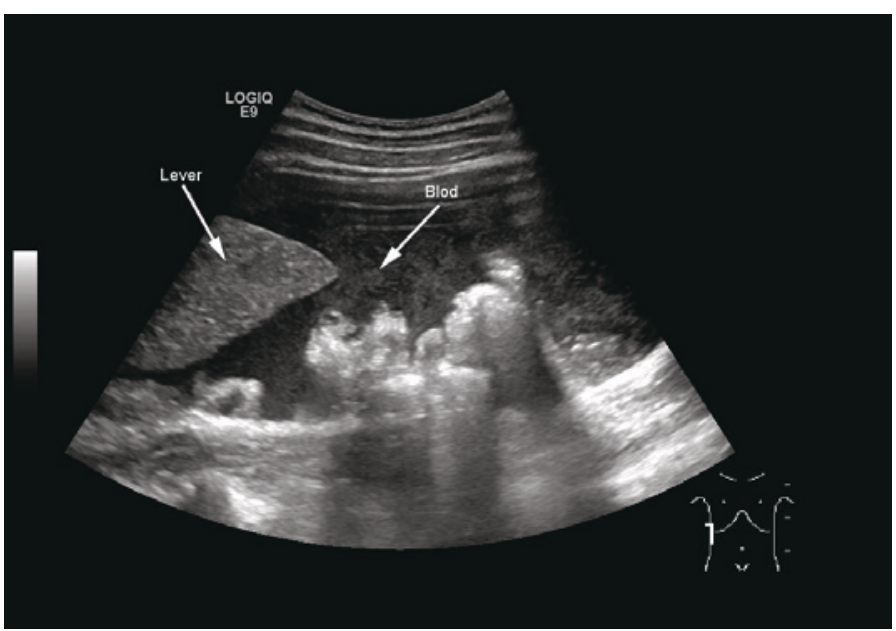

Figur 2 Ultralyd abdomen viste store mengder fri væske i buken med ekkomønster forenlig med blod

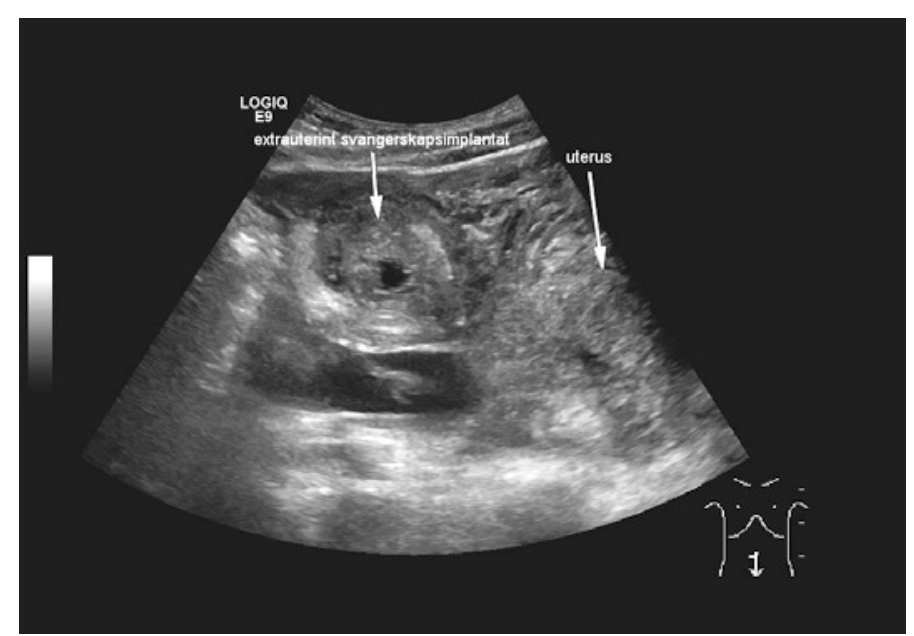

Figur 3 Ultralyd abdomen viste uregelmessig oppfylning påca. $5 \mathrm{~cm}$ like kranialt for uterus, forenlig med ekstrauterin graviditet 


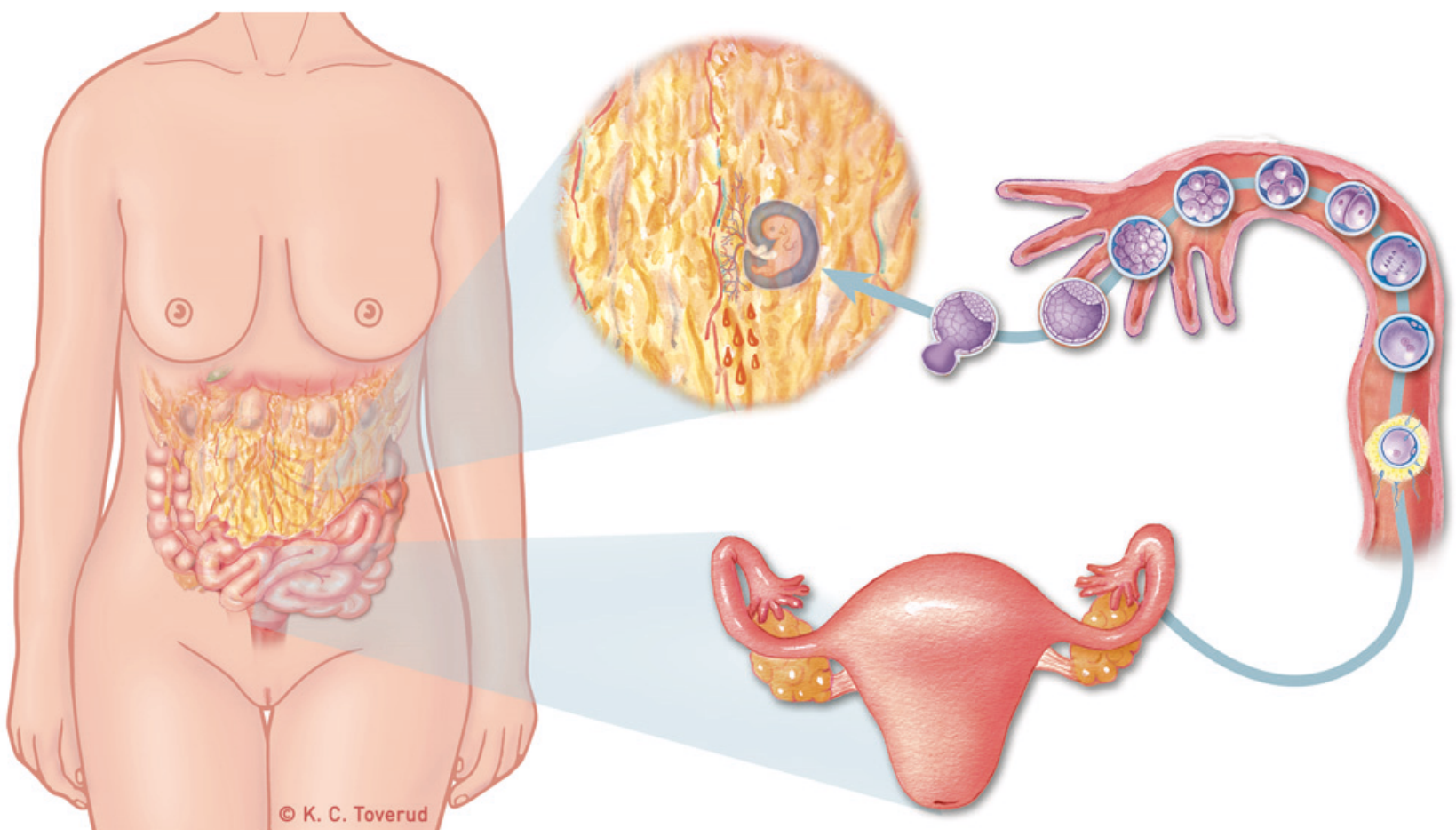

Figur 4 Illustrasjon av sekundær implantasjon på omentum majus

det skjedd en implantasjon i omentum majus som etter hvert ga smerter og alvorlig abdominalblødning.

\section{Diskusjon}

Ektopisk graviditet forekommer i rundt $1-2 \%$ av alle svangerskap $(4,5)$, og om lag $30 \%$ av disse ender med tuberuptur (6). Den relativt høye prevalensen og tilstandens alvorlighetsgrad gjør ektopisk graviditet til en viktig differensialdiagnose ved akutte magesmerter hos kvinner i fertil alder.

Det vanligste implantasjonssted ved ektopisk graviditet er i ampulla tubae, lateralt for isthmus. Andre steder kan være i fimbriae, ovarier, innmunningen fra tuben til uterinhulen (angulær implantasjon) og ulike steder i bukhulen (7). Implantasjonen kan være primær eller sekundær $(8,9)$. Ved sekundær implantasjon har den primære innleiringen av blastocysten i adnexa blitt spontant avstøtt for så å reimplanteres et annet sted i abdominalhulen. Her kan egget i prinsippet implanteres hvor som helst, men det blir sjeldnere jo lenger bort fra ovariet man kommer. Det er rapportert tilfeller med sekundær implantasjon på ligamentum latum, uterus' overflate, bukvegg, tarmer - og altså på omentum majus (10). I figur 4 illustreres sekundær implantasjon på omentum majus.

Disponerende faktorer for ektopisk graviditet omfatter bl.a. gjennomgått salpingitt, tidligere infertilitet, tidligere ektopisk graviditet og tubekirurgi, prevensjonssvikt ved bruk av kobberspiral og prevensjonssvikt ved sterilisering (11). Ifølge vår pasient var ingen av disse faktorene aktuelle for henne.

Ved ektopisk graviditet starter det tidlige symptomstadiet normalt 6-8 uker etter siste blødning. Det arter seg ofte som episodiske anfall av ensidige, krampeliknende smerter, gjerne av «murrende karakter» (4). Disse symptomene kan ledsages av sparsomme blødninger, men kan en sjelden gang også opptre uten blødninger. Dette tidlige, symptomfattige stadiet kan trekke ut over flere uker, noe som vanskeliggjør diagnostiseringen. Ved en ruptur vil symptomene være akuttpreget, med kraftige smerteanfall, sympatikusaktivering og i noen tilfeller tegn på hypovolemisk sjokk.

\section{Abdominal implantasjon}

Abdominal implantasjon opptrer kun i om lag $1-2 \%$ av alle ektopiske graviditeter (10), og av disse er omental implantasjon den sjeldneste. I en artikkel fra 2008 refererer man at kun 16 tilfeller var rapportert i litteraturen til da, hvorav de fleste var sekundære (12).

En abdominal graviditet med implantasjon i omentum majus vil gjerne være symptomfattig tidlig i forløpet, og kvinnen vil oftest ikke oppfatte at hun er gravid. Blødning er et lite spesifikt symptom, siden langt fra alle opplever det og mengden er beskjeden (3). Amnion og chorion vil imidlertid være lettblødende, og i motsetning til forløpet ved en tubar ruptur vil en abdominal graviditet - avhengig av implantasjonssted - kunne forårsake mindre profuse blødninger. Slike blødninger kan imidlertid være med på å gi dårligere prognose ved en ruptur. Maternell mortalitet ved abdominal graviditet ligger på rundt $6 \%$ (5). Vår pasient hadde mistet ca. 21 blod og faren for alvorlige komplikasjoner som blødningssjokk var stor.

\section{Intervensjon}

Ved mistanke om ektopisk graviditet gjøres vanligvis laparoskopi (13). Tidlige tubare graviditeter kan imidlertid være vanskelige å diagnostisere ved laparoskopi og ved sekundær abdominal implantasjon vil det være enda vanskeligere å lokalisere graviditeten. Spesielt gjelder dette ved bifunn i adnexa, da man kan forledes til å tro at den primære implantasjonen her fremdeles er sete for graviditeten. I slike tilfeller kan man komme til å utføre en salpingektomi - uten å få med seg konsepsjonsproduktene og med fortsatt fare for abdominal blødning og hypovolemisk sjokk.

Vi mener at man i vanskelige tilfeller bør bruke laparoskopi som diagnoseverktøy og lete systematisk etter mulige sekundærfokus som kan forklare pasientens symptomer. Man bør også vurdere muligheten for at det kan være flere parallelt forløpende patologiske prosesser. Kvinner med en sykehistorie forenlig med ektopisk graviditet og negative funn ved laparoskopi bør følges tett opp og vurderes for omental implantasjon til tross for at denne diagnosen har lav prevalens (14). 
HCG

Ved ektopisk graviditet vil HCG normalt ligge lavere enn ved intrauterin graviditet av tilsvarende varighet. Man vil heller ikke se den typiske doblingen i HCG-verdier hver andre dag tidlig i forløpet (15). Seriemålinger er derfor et viktig diagnosekriterium for denne tilstanden, og muliggjør, sammen med vaginal ultralyd, tidlig diagnose. Men, som man tydelig fikk demonstrert $\mathrm{i}$ vårt tilfelle, kan man ikke alltid stole blindt på laboratorieprøver og andre tester. Graviditetstesten som pasienten tok hjemme var negativ, mens HCG-nivået i serum var klart positivt. Det kan være flere grunner til at man her fikk motstridende svar på de to graviditetstestene. Det er viktig å merke seg at urinbaserte hjemmetester kan ha noe lavere sensitivitet enn HCG i serum. Dette er spesielt relevant ved ektopisk graviditet, der HCG-nivåene gjerne er lavere enn ved intrauterin graviditet.

Mulige feilkilder ved hjemmetesting er blant annet feil avlesning, unøyaktig applikasjon, for lite prøvemateriale samt kontaminasjon av prøvematerialet. I dette tilfellet kan man heller ikke utelukke at det var en direkte defekt ved den aktuelle testen, da den normalt skal gi positivt utslag allerede ved et HCG-titer på 25-50 IE/1.

I ettertid kan man se at det skulle vært tatt en ny graviditetstest på legevakten. Det ville ha lettet utredningen og man ville sannsynligvis ha unngått å sende pasienten til «feil» sykehus med tilsvarende lengre transportvei. Hos unge kvinner med magesmerter er det altså en god regel å ta HCG i urin rutinemessig, uavhengig av hva som er gjort utenfor sykehuset.
Pasienten har gitt samtykke til at artikkelen blir publisert.

Vi takker Radiologisk avdeling ved sykehuset Molde for hjelp til å hente frem og velge ut ultralydbildene.

\section{Peter Erik Petersen (f. 1968)}

er medisinstudent og har arbeidet som lege med midlertidig lisens ved Kirurgisk avdeling Molde sykehus.

Forfatter har fylt ut ICMJE-skjemaet og oppgir ingen interessekonflikter.

\section{Kjell Isachsen jr. (f. 1961)}

er spesialist i fødselshjelp og kvinnesykdommer og er overlege.

Forfatter har fylt ut ICMJE-skjemaet og oppgir ingen interessekonflikter.

\section{Mark Berner Hansen (f. 1960)}

er dr.med. og spesialist i gastroenterologisk kirurgi. Han er vikarierende overlege ved Kirurgisk avdeling, Molde sykehus, seniorforsker ved Kirurgisk avdeling, Bispebjerg Hospital og Medical Science Director ved AstraZeneca, Mölndal, Sverige.

Forfatter har fylt ut ICMJE-skjemaet og oppgir ingen interessekonflikter.

\section{Litteratur}

1. Grundmann RT, Petersen M, Lippert $\mathrm{H}$ et at. The acute (surgical) abdomen - epidemiology, diagnosis and general principles of management. Z Gastroenterol 2010; 48: 696-706.

2. Lyon C, Clark DC. Diagnosis of acute abdominal pain in older patients. Am Fam Physician 2006; 74: $1537-44$
3. Lozeau A-M, Potter B. Diagnosis and management of ectopic pregnancy. Am Fam Physician 2005: 72: 1707-14

4. Bergsjø P, Maltau JM, Molne K et al. Obstetrikk og gynekologi. Oslo: Gyldendal Akademisk, 2010.

5. Onan MA, Turp AB, Saltik A et al. Primary omental pregnancy: case report. Hum Reprod 2005; 20 : $807-9$

6. Job-Spira N, Fernandez H, Bouyer J et al. Ruptured tubal ectopic pregnancy: risk factors and reproductive outcome: results of a populationbased study in France. Am J Obstet Gynecol 1999; 180: $938-44$

7. Bouyer J, Coste J, Fernandez H et al. Sites of ectopic pregnancy: a 10 year population-based study of 1800 cases. Hum Reprod 2002; 17: 3224-30.

8. Karaer Ö, Ilkgül Ö, Oruç S. Primary omental pregnancy on the gastrocolic ligament. South Med J 2007; 100: 403-4

9. Studdiford WE. Primary peritoneal pregnancy. Am J Obstet Gynecol 1942; 44: 487-91.

10. Atrash HK, Friede A, Hogue CJ. Abdominal pregnancy in the United States: frequency and maternal mortality. Obstet Gynecol 1987; 69: 333-7.

11. Chow W-H, Daling JR, Cates W Jr et al. Epidemiology of ectopic pregnancy. Epidemiol Rev 1987, 9: $70-94$

12. Chopra S, Keepanasseril A, Suri V et al. Primary omental pregnancy: care report and review of literature. Arch Gynecol Obstet 1990: 279: 441-2.

13. Tulandi T, Saleh A. Surgical management of ectopic pregnancy. Clin Obstet Gynecol 1999; 42: $31-8$ quiz 55-6.

14. Behjati S, Bamfo JEAK, Bates AW et al. A near miss: lessons from a case of omental pregnancy. J Obstet Gynaecol 2009; 29: 559-60.

15. Bischof P, Reyes H, Herrmann WL et al. Circulating levels of pregnancy-associated plasma protein-A (PAPP-A) and human chorionic gonadotrophin (hCG) in intrauterine and extrauterine pregnancies. Br J Obstet Gynaecol 1983; 90: 323-5.

Mottatt 16.11. 2012, første revisjon innsendt 12.4 2013, godkjent 1.7. 2013. Redaktør Merete Kile Holtermann.

\section{Kommentar}

\section{Akutte magesmerter - de vanlige mistenkte?}

Magesmerter utgjør en stor andel av årlige besøk til legevakt og akuttmottak. Tall fra Trondheim viser at pasienter med abdominalsmerter står for $13 \%$ av kontaktene, mens brystsmerter (13\%) og dyspné (9\%) utgjør de to andre største gruppene (1). Akutte magesmerter er også en vanlig årsak til at pasienter oppsøker allmennlege. I en norsk studie kunne rundt $75 \%$ av dem som oppsøkte allmennlegen for akutte magesmerter håndteres av legen selv eller sendes hjem uten videre tiltak, mens en firedel behøvde innleggelse og videre utredning i sykehus (2). De vanligste diagnosene i denne begrensede kohorten på 134 pasienter var ikke-spesifikke magesmerter (20\%), gastroenteritt $(13 \%)$, akutt appendisitt $(12 \%)$, magesår $(11 \%)$, gynekologiske sykdommer $(9 \%)$ og urinveisproblematikk (7\%). Selv om fordelingen av diagnoser varierer noe fra studie til studie, er det vanlige det vanligste også i denne kliniske sammenhengen. Det gjør det lett å overse andre, sjeldnere og noen ganger alvorlige diagnoser. Utfordringen er derfor å huske på andre mulige differensialdiagnoser når kliniske funn og prøveresultater ikke passer helt med det man forventer.

Differensialdiagnosene ved akutte magesmerter er mange, og oversikt over årsaker og smertenes lokalisasjon finnes i de fleste lærebøker. Uvanlige presentasjoner eller spesielt vanskelige tilfeller er klinisk utfordrende og presenteres fortsatt i form av kasuistikker i de fleste tidsskrifter $(3,4)$. Den diagnostiske treffsikkerheten for enkeltfunn eller biokjemiske prøver varierer, og falskt negative svar kan forekomme. Det belyses ved den negative graviditetstesten i kasuistikken fra Petersen og medarbeidere. Såkalte «hjemmetester» opplyses ofte å være over $99 \%$ sikre, men det vil alltid være noe usikkerhet knyttet til en slik test. Det kan blant annet skyldes uvisshet rundt tidspunkt for siste menstruasjon og variasjon i HCGnivåer i blod mellom kvinner samt brukerens 